\title{
BMJ Open Do baby boomers use more healthcare services than other generations? Longitudinal trajectories of physician service use across five birth cohorts
}

\author{
Mayilee Canizares, ${ }^{1,2}$ Monique Gignac, ${ }^{2,3}$ Sheilah Hogg-Johnson, ${ }^{3,4}$ \\ Richard H Glazier, ${ }^{5,6,7}$ Elizabeth M Badley ${ }^{2,4}$
}

To cite: Canizares $\mathrm{M}$, Gignac M, Hogg-Johnson S, et al. Do baby boomers use more healthcare services than other generations? Longitudinal trajectories of physician service use across five birth cohorts. BMJ Open 2016:6:e013276.

doi:10.1136/bmjopen-2016013276

- Prepublication history and additional material is available. To view please visit the journal (http://dx.doi.org/ 10.1136/bmjopen-2016013276).

Received 30 June 2016 Revised 22 August 2016 Accepted 26 August 2016

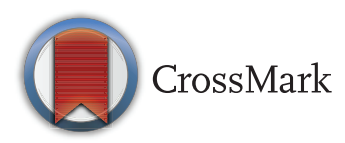

For numbered affiliations see end of article.

Correspondence to

Mayilee Canizares;

mcanizar@uhnres.utoronto.ca

\section{ABSTRACT}

Objective: In light of concerns for meeting the provision of healthcare services given the large numbers of ageing baby boomers, we compared the trajectories of primary care and specialist services use across the lifecourse of 5 birth cohorts and examined factors associated with birth cohort differences.

Design: Longitudinal panel.

Setting: Canadian National Population Health Survey (1994-2011).

Population: Sample of 10186 individuals aged 2069 years in 1994-1995 and who were from 5 birth cohorts: Generation X (Gen X; born: 1965-1974), Younger Baby Boomers (born: 1955-1964), Older Baby Boomers (born: 1945-1954), World War II (born: 1935-1944) and pre-World War II (born: 1925-1934).

Main outcomes: Use of primary care and specialist services.

Results: Although the overall pattern suggested less use of physician services by each successive recent cohort, this blinded differences in primary and specialist care use by cohort. Multilevel analyses comparing cohorts showed that Gen Xers and younger boomers, particularly those with multimorbidity, were less likely to use primary care than earlier cohorts. In contrast, specialist use was higher in recent cohorts, with Gen Xers having the highest specialist use. These increases were explained by the increasing levels of multimorbidity. Education, income, having a regular source of care, sedentary lifestyle and obesity were significantly associated with physician services use, but only partially contributed to cohort differences.

Conclusions: The findings suggest a shift from primary care to specialist care among recent cohorts, particularly for those with multimorbidity. This is of concern given policies to promote primary care services to prevent and manage chronic conditions. There is a need for policies to address important generational differences in healthcare preferences and the balance between primary and specialty care to ensure integration and coordination of healthcare delivery.

\section{Strengths and limitations of this study}

- No study has compared the patterns of primary care and specialist service use among baby boomers and other generations.

- Large longitudinal data, spanning 18 years, enabled us to compare different cohorts at the same chronological age.

- Our analytical methodology integrated changes in healthcare use indicators with changes in factors associated with them.

- The interpretation of the findings is limited due to the inability to identify the specific conditions for which individuals are consulting with physicians.

- The data are self-reported and the bias associated with inaccuracies and reporting errors is unknown.

\section{INTRODUCTION}

Older age is typically associated with worse health, higher healthcare use $\mathrm{u}^{1-3}$ and increased healthcare costs. ${ }^{4-6}$ Consequently, the large number of ageing baby boomers (born 1945-1964), who are now 50+ years of age, are generating concerns for the provision of health services in North America and elsewhere. Two issues have been raised: the large size of the cohort and the belief that baby boomers are different in their needs and attitudes towards healthcare from their predecessors. ${ }^{7-11}$ Baby boomers grew up at a time of social change, economic growth and prosperity with improved access to education, employment opportunities, and with access to health and welfare services. ${ }^{12-14}$ They are the first generation to have access to antibiotics and other effective medications. On one hand, these advances have the potential to improve the health of boomers and reduce their need for healthcare services. On the other hand, these advantages have also con- 
tributed to longer life expectancy and improvements in survival. As a result, people are living longer with the potential of developing multiple chronic conditions and hence needing more healthcare services. ${ }^{15} 16$

Parallel to these changes, baby boomers and succeeding generations have also been part of a shift to consumer-driven healthcare where people define themselves first as consumers and then as patients. This consumer market has positioned health as an individual right, and as a result, many people have proactive behaviours towards their health decisions and selection of services. ${ }^{17-19}$ Boomers are often avid consumers of health information and are more willing to try new treatments than previous generations. ${ }^{20}{ }^{21}$ Yet, how changes in prosperity, medical care improvements and the rise in medical consumerism affect baby boomers' use of health services remains to be examined. Studies have not investigated whether there are generational differences in healthcare use, including consultations with primary physicians and specialists. Formulating policy changes and interventions to accommodate the needs of this large cohort will require a thorough understanding of these patterns and the diverse factors affecting healthcare use in boomers and other cohorts.

Andersen and Newman's behavioural model of health services is useful for identifying factors related to healthcare use. ${ }^{22}{ }^{23}$ In their framework, healthcare use is conceptualised as a function of predisposing (eg, age, sex, education), enabling (eg, income, regular source of care) and need (eg, chronic health conditions) factors. Behaviour-related risk factors (eg, obesity) can also be included in the framework. Previous research has found cohort differences related to a number of factors relevant to healthcare use of baby boomers and other cohorts. For example, improvements in the standard of living and education attainment since the $1950 \mathrm{~s}^{24} 25$ might be expected to reduce the need for healthcare among baby boomers and succeeding generations. Declines in smoking rates in recent cohorts ${ }^{26-28}$ are also likely to be related to better health and reduced healthcare. ${ }^{29}{ }^{30}$ However, trends of increased obesity and sedentary lifestyles in each succeeding recent cohort ${ }^{29} 31-34$ are risk factors for worse health and may result in increased healthcare use. ${ }^{303536}$ Few studies have explicitly compared need factors like chronic health conditions across cohorts. An Australian study found that Generation X (Gen Xers) reported more diabetes than baby boomers ${ }^{34}$ and a study from the $\mathrm{UK}^{37}$ found that boomers had more hypertension and diabetes than their predecessors. In contrast, a study of US women found no differences in arthritis prevalence between baby boomers and the previous generation. ${ }^{38}$

Given the lack of evidence on patterns of healthcare use among baby boomers compared to other generations, this study uses longitudinal panel data spanning 18 years to compare use of physician services (primary care and specialist care) across five birth cohorts: Gen X (born: 1965-1974), Younger Baby Boomers (born: 1955-
1964), Older Baby Boomers (born: 1945-1954), World War II (born: 1935-1944) and pre-World War II (born: 1925-1934). The overall goal was to (1) compare primary care and specialist services use over the lifecourse across birth cohorts and (2) to examine cohort differences in predisposing, enabling, need and behaviour-related risk factors that could explain cohort differences in the lifecourse trajectories of primary care and specialist use.

\section{METHODS}

\section{Study setting and population}

We used data from the longitudinal component of the Canadian National Population Health Survey (NPHS) spanning 18 years from 1994 to 2011. The NPHS, established in 1994-1995 (cycle 1), is a representative sample of the household population residing in Canada's 10 provinces. The survey excluded persons living on Indian Reserves and Crown Lands, residents of health institutions, full-time members of the Canadian Forces Bases and some remote areas in Ontario and Québec. The NPHS retained individuals who moved to long-term care institutions and those who died over the course of the survey. ${ }^{39} \mathrm{We}$ included participants who were between 20 and 69 years old in 1994, contributed to at least three cycles of data and had complete information about the outcomes at baseline (1994). This resulted in a sample of 10186 individuals with an average of seven cycles of data. The University of Toronto Ethics Committee approved the study.

\section{Data sharing}

The survey is not publicly available and authorisation from Statistics Canada is required to access the data. Therefore, there are no additional data available.

\section{Primary outcomes}

At each cycle, participants were asked about their use of healthcare in the previous 12 months. Canada has a national healthcare policy which provides universal coverage for all medically necessary hospital and physician services with no copayments or other patient charges. Access to specialists is by referral from other physicians, usually a family physician/general practitioner (FP/GP). Participants were asked to report the number of consultations with FP/GPs or specialists (excluding eye care) in the 12 months prior to their interview. Since our focus was to study services for health conditions and not wellcare visits for screening and immunisation, we defined primary care use as reporting two or more FP/GP visits and specialist use as reporting at least one visit to a specialist. In this paper, we use the term 'primary care' to have the same meaning as 'FP/GP'. Furthermore, specialists like those in general internal medicine do not have primary care roles in Canada.

\section{Predictors}

Cohort membership and age were based on year of birth. Participants were allocated in five birth cohorts: 
Gen X (born: 1965-1974), Younger Baby Boomers (born: 1955-1964), Older Baby Boomers (born: 19451954), World War II (born: 1935-1944) and pre-World War II (born: 1925-1934). We used Andersen and Newman's model of healthcare use to select variables. ${ }^{23}$ Measures of predisposing factors were gender and education. Education was measured as years of schooling and was grouped for analyses as: $<12,12-15$ and 16 +years. Enabling factors were household income and having a regular source of care. Household income was collected at each cycle and categorised into quartiles of the distribution at each survey year with a separate category representing missing values. We used the presence of chronic conditions as an indicator of need for care. At each cycle, respondents indicated yes/no to the presence of 17 chronic conditions diagnosed by a healthcare professional. The number of chronic conditions was grouped as: none, 1 and $2+$.

We also examined behaviour-related factors: smoking, obesity, physical activity and sedentary lifestyle. Participants were grouped as: current smoker, former smoker and non-smoker (those who never smoked). We grouped body mass index as: underweight $(<18.5)$, normal weight (18.5-24.9), overweight (25.0-29.9), moderate obese (30.0-34.9) and severe obese $(\geq 35.0){ }^{40}$ The survey asked a series of questions about participation in physical activities like walking for exercise, running, gardening and collected the time per week participants usually spent walking (bicycling) to work, school or while doing errands. Responses were used to group individuals as physically active (during leisure time or active commuting) versus inactive based on Statistics Canada-derived variables. ${ }^{39}$ Finally, participants who reported that they 'usually sit during the day and don't walk around very much' were considered to have a sedentary lifestyle.

\section{Statistical analysis}

Comparing birth cohorts is complex because cohort differences are linked to the effects of ageing as well as societal and environmental changes affecting the population as a whole (period effects). Therefore, in addition to age, it is pertinent to consider period effects (eg, survey year), as these may obscure cohort effects unless they are properly modelled. However, studies aiming to estimate the effects of age, period and cohort are hindered by the identification problem; that is, age, period and cohort are linearly dependent. ${ }^{41}$ Because of this linearity, there is no unique solution to models, including the three effects simultaneously. As a result, they cannot be modelled at once. One way to deal with this problem is to directly estimate age and cohort effects (as fixed effects) while accounting for variability across periods (random effect) (see discussion in Bell ${ }^{41}$ and Suzuki ${ }^{42}$ ). To do this, we fitted cross-classified multilevel models in which observations were nested within individuals and individuals were nested within time periods.
We started with a model with age and cohort (model 1). In the next steps, we added predisposing, enabling and behaviour-related factors (model 2). And finally, we added need factors (model 3) and examined variations in the age and cohort estimates. In all models, age was centred at 39 years (the mean of the distribution for the five cohorts at baseline (1994-1995)). Models were fitted using PROC GLIMMIX from SAS V.9.3, including incomplete cases up to the point at which they drop out or died and likelihood estimators were used that adjust for nonresponse assuming that the data are missing at random. The significance of variables was assessed by Wald tests.

\section{Supplementary analyses}

We conducted three sets of supplementary analyses. First, we repeated the analyses using the number of visits to FP/GPs, to specialists and the total number of visits as the outcomes. We also modelled primary care use defined as having at least one visit to FP/GPs. Second, using the number of chronic conditions as a global measure of need for care precluded us from elucidating the effects of individual chronic conditions in explaining cohort differences in the outcomes. Therefore, we repeated the analysis 17 times by adding each individual chronic condition to the models and examined changes in the cohort coefficients. Finally, we examined the impact of attrition in our analyses by comparing the results of the models including indicator variables identifying participants who dropped out or died before the end of the study and the results of restricting the analyses to individuals with complete data in the nine cycles.

\section{Patient involvement}

This study is based on a population survey that did not involve patients.

\section{RESULTS}

\section{Descriptive}

In 1994-1995, there were 10186 participants who met the inclusion criteria: 1384 in the pre-World War II cohort, 1596 in the World War II cohort, 2205 Older Baby Boomers, 2778 Younger Baby Boomers and 2223 Gen Xers. Generally, physician services use was higher in women than men overall and for primary care and specialist use (table 1). Women reported having a regular source of care more often than men in all cohorts, with the exception of the pre-World War II cohort. Education was higher for younger boomers and Gen Xers, while older boomers had the highest income. Men reported slightly higher household income than women in all cohorts. Dropping out of the study was the most common source of attrition among baby boomers and Gen Xers and death in the pre-World War II cohort (table 1). In preliminary analyses, we found significant differences in the outcomes and predictors by gender; therefore, results are presented for women and men separately. 
Table 1 Characteristics of birth cohorts at baseline (1994-1995). Canadian NPHS, 1994-2011

\begin{tabular}{|c|c|c|c|c|c|c|c|c|c|c|}
\hline & \multicolumn{2}{|c|}{$\begin{array}{l}\text { Pre-World } \\
\text { War II (1925- } \\
\text { 1934) }\end{array}$} & \multicolumn{2}{|c|}{$\begin{array}{l}\text { World War II } \\
(1935-1944)\end{array}$} & \multicolumn{2}{|c|}{$\begin{array}{l}\text { Older baby } \\
\text { boomer } \\
(1945-1954)\end{array}$} & \multicolumn{2}{|c|}{$\begin{array}{l}\text { Younger Baby } \\
\text { Boomer } \\
(1955-1964)\end{array}$} & \multicolumn{2}{|c|}{$\begin{array}{l}\text { Gen X (1965- } \\
1974)\end{array}$} \\
\hline & Women & Men & Women & Men & Women & Men & Women & Men & Women & Men \\
\hline $\mathrm{N}$ & 787 & 597 & 857 & 739 & 1150 & 1055 & 1510 & 1268 & 1201 & 1022 \\
\hline \multicolumn{11}{|l|}{ Outcomes } \\
\hline$\%$ physician services use & 75.2 & 66.6 & 69.9 & 57.9 & 67.3 & 51.7 & 71.3 & 48.4 & 76.7 & 43.1 \\
\hline$\%$ primary care users & 69.5 & 59.6 & 64.1 & 51.8 & 60.4 & 46.5 & 63.4 & 43.5 & 69.3 & 38.5 \\
\hline$\%$ specialist users & 31.9 & 30.0 & 31.2 & 24.5 & 31.4 & 19.2 & 33.4 & 17.2 & 34.1 & 13.1 \\
\hline \multicolumn{11}{|l|}{ Enabling factors } \\
\hline Mean age & 63.7 & 63.8 & 53.8 & 53.6 & 43.6 & 43.8 & 33.9 & 34.0 & 24.2 & 24.2 \\
\hline Mean years of schooling & 10.7 & 10.7 & 11.7 & 11.8 & 13.2 & 13.1 & 13.3 & 13.4 & 13.5 & 13.5 \\
\hline \multicolumn{11}{|l|}{ Predisposing factors } \\
\hline Mean household income* & 40.7 & 45.4 & 54.7 & 59.0 & 59.7 & 62.3 & 53.6 & 56.2 & 49.7 & 54.7 \\
\hline$\%$ with regular doctor & 94.7 & 93.1 & 93.6 & 88.7 & 90.1 & 80.6 & 89.8 & 78.9 & 87.8 & 70.3 \\
\hline \multicolumn{11}{|l|}{ Behaviour-related factors } \\
\hline$\%$ smokers (current or former) & 54.4 & 80.8 & 53.1 & 76.8 & 56.8 & 71.7 & 62.0 & 63.8 & 59.1 & 54.4 \\
\hline Mean BMI & 26.1 & 26.6 & 26.2 & 26.9 & 25.3 & 26.5 & 24.2 & 26.0 & 23.4 & 24.7 \\
\hline$\%$ obese & 18.5 & 18.9 & 16.3 & 16.6 & 16.1 & 14.7 & 11.6 & 11.4 & 10.1 & 10.0 \\
\hline$\%$ physically inactive & 44.1 & 49.1 & 41.9 & 39.3 & 38.7 & 46.4 & 42.1 & 48.0 & 47.0 & 55.0 \\
\hline$\%$ sedentary & 17.1 & 19.9 & 17.2 & 21.4 & 22.7 & 22.0 & 20.4 & 21.3 & 22.1 & 18.2 \\
\hline \multicolumn{11}{|l|}{ Need factors } \\
\hline Mean number of chronic conditions & 1.6 & 1.4 & 1.3 & 1.0 & 0.9 & 0.7 & 0.8 & 0.6 & 0.7 & 0.5 \\
\hline$\%$ with 1 chronic condition & 29.7 & 32.9 & 29.7 & 36.1 & 31.8 & 29.9 & 28.5 & 30.1 & 26.5 & 26.5 \\
\hline$\%$ with $2+$ chronic conditions & 43.0 & 38.2 & 34.6 & 25.0 & 21.2 & 17.5 & 18.7 & 13.5 & 18.4 & 10.7 \\
\hline \multicolumn{11}{|l|}{ Attrition† } \\
\hline$\%$ died & 30.3 & 48.9 & 11.7 & 19.3 & 5.4 & 6.1 & 1.7 & 3.1 & 1.7 & 2.6 \\
\hline$\%$ dropped-out & 19.8 & 21.0 & 20.2 & 25.3 & 23.5 & 23.5 & 28.0 & 30.2 & 34.1 & 37.8 \\
\hline
\end{tabular}

\section{Cohort differences in healthcare use}

Cohort differences in the overall pattern of physician services use were modest and suggested less use of services by each successive recent cohort. However, these modest differences blinded marked cohort differences in primary care and specialist care (table 2). We therefore analysed data for primary care and specialist care separately.

In addition, the age and cohort patterns of physician services use were different for men and women. For women, primary care use declined around age 40, and then increased as they grew older; whereas for men, primary care use increased steadily with increasing age. Although specialist use increased with increasing age for women and men, this increase was more marked for men than women (figure 1A, B, respectively). In addition to age effects, we found significant cohort differences in primary care use for women but not for men (table 2, figure 1A). Comparing women at corresponding ages indicated that Gen Xers and younger boomers had the lowest primary care use. Likewise, there were significant cohort differences in specialist use for women and men. In contrast to primary care use, comparing people at the same ages there was higher specialist use in each succeeding recent cohort (table 2, figure 1B).
In all models, we controlled for the potential of period effects. We found only a minimal variability across years for primary care use by women and no differences for men. No significant period effects were seen for specialist use (table 2).

\section{Explaining cohort differences}

Predisposing, enabling and behavioural risk factors

There were significant associations of predisposing, enabling and behaviour-related factors with primary care and specialist care use (tables 3 and 4, model 2) that were somewhat attenuated once the number of chronic conditions was entered into the models (model 3). Specifically, there were no differences in primary care use related to education (predisposing factor), but education was significantly associated with specialist use: women and men with higher education were more likely to visit specialists than those with lower education. For enabling factors, income was significantly associated with primary care use for men only: those in the top income quartile were less likely to visit $\mathrm{FP} / \mathrm{GPs}$ than those in the bottom quartile ( $\mathrm{OR}=0.89,95 \%$ CI 0.81 to 0.99 ). Income was not significantly associated with specialist use for either women or men. Women and men with a regular source of care were more likely to consult with FP/GPs and see specialists. 
Table 2 Age and cohort effects (model 1) on physician services use: results from logistic cross-classified multilevel models. Canadian NPHS, 1994-2011

$\begin{array}{lll}\text { Any physician use } & \text { Primary care } & \text { Specialist care } \\ \text { OR }(95 \% \mathrm{Cl}) & \text { OR }(95 \% \mathrm{Cl}) & \text { OR }(95 \% \mathrm{Cl})\end{array}$

\section{Women}

Fixed effects

Age and cohort effects

Linear age‡

Birth cohort (Ref: pre-World War)

World War II

Older Baby Boomer

Younger Baby Boomer

OR $(95 \% \mathrm{Cl})$

OR $(95 \% \mathrm{Cl})$

Gen X

Random effects§

Individual

Period (survey year)

Men

Fixed effects

Age and cohort effects

Linear age

Birth cohort (Ref: Pre-World War)

World War II

Older Baby Boomer

Younger Baby Boomer

Gen X

Random effects§

Individual

Period (survey year)

$\begin{array}{ll}0.99(0.98 \text { to } 0.99)^{\star \star \star} & 0.99(0.98 \text { to } 1.00)^{\star \star \star} \\ 1.23(1.04 \text { to } 1.45)^{\star} & 1.08(0.91 \text { to } 1.29) \\ 1.08(0.90 \text { to } 1.31) & 0.96(0.77 \text { to } 1.19) \\ 0.94(0.76 \text { to } 1.15) & 0.84(0.63 \text { to } 1.10) \\ 0.91(0.73 \text { to } 1.15) & 0.79(0.64 \text { to } 0.99)^{\star \star}\end{array}$

$1.32(1.28 \text { to } 1.34)^{\star \star \star}$

0.01 (0.00 to 0.03 )

$1.03(1.02 \text { to } 1.03)^{\star \star *}$

$1.32(1.10 \text { to } 1.59)^{* *}$

$1.36(1.12 \text { to } 1.66)^{\star *}$

$1.47(1.18 \text { to } 1.82)^{\star *}$

$1.48(1.16 \text { to } 1.88)^{* *}$

$1.27(1.11 \text { to } 1.34)^{\star \star \star}$

$0.01(0.00$ to 0.04$)$
$1.39(1.31 \text { to } 1.47)^{\star \star \star}$

$0.01(0.00 \text { to } 0.01)^{*}$

$1.01(1.00 \text { to } 1.02)^{\star \star}$

$1.38(1.20 \text { to } 1.58)^{\star \star \star}$

$1.49(1.25 \text { to } 1.78)^{\star \star \star}$

$1.48(1.19 \text { to } 1.83)^{\star \star \star}$

$1.67(1.29 \text { to } 2.15)^{\star \star \star}$

$0.91(0.85 \text { to } 0.97)^{\star \star \star}$

$0.00(-0.04$ to 0.04$)$

$1.02(1.01 \text { to } 1.03)^{\star \star \star}$

$1.03(1.02 \text { to } 1.04)^{* \star \star}$

$1.16(0.97$ to 1.39$)$

1.09 (0.90 to 1.33$)$

1.03 (0.81 to 1.30$)$

0.99 (0.99 to 0.99 )

$1.32(1.11 \text { to } 1.58)^{\star \star \star}$

$1.36(1.10 \text { to } 1.69)^{\star \star \star}$

$1.52(1.18 \text { to } 1.96)^{\star \star \star}$

$1.73(1.27 \text { to } 2.37)^{\star \star \star}$

$1.37(1.31 \text { to } 1.43)^{\star \star \star *}$

$0.87(0.79 \text { to } 0.95)^{\star \star \star}$

$0.00(-0.04$ to 0.04$)$


Figure 1 Age trajectories and birth cohort for $(A)$ primary care use and $(B)$ specialist care use. Values are predictions from the fixed part of models in table 2. GenX, Generation X; OBB, Older Baby Boomer; pre-WW, pre-World War II; YBB, Younger Baby Boomer; WW2, World War II.

Behaviour-related factors were significantly associated with primary care and specialist use. Those who reported sedentary lifestyles and physically active women were more likely to consult with both types of practitioners. Smoking was not associated with primary care use, but it was associated with specialist use for men: former smokers were more likely to visit specialists than nonsmokers (OR=1.15, 95\% CI 1.04 to 1.26$)$. Obesity was not significantly associated with specialist use, but obese individuals were more likely to see FP/GPs. 
Table 3 Predisposing, enabling, behaviour-related and need factors as predictors of physician use for women: results from logistic cross-classified multilevel models.‡ Canadian NPHS, 1994-2011

\begin{tabular}{|c|c|c|c|c|}
\hline & \multicolumn{2}{|l|}{ Primary care } & \multicolumn{2}{|l|}{ Specialist care } \\
\hline & $\begin{array}{l}\text { Model } 2 \\
\text { OR }(95 \% \mathrm{Cl})\end{array}$ & $\begin{array}{l}\text { Model } 3 \\
\text { OR }(95 \% \mathrm{Cl})\end{array}$ & $\begin{array}{l}\text { Model } 2 \\
\text { OR }(95 \% \mathrm{Cl})\end{array}$ & $\begin{array}{l}\text { Model } 3 \\
\text { OR }(95 \% \mathrm{CI})\end{array}$ \\
\hline \multicolumn{5}{|l|}{ Age and cohort effects } \\
\hline Linear age§ & $0.85(0.84 \text { to } 0.86)^{\star \star *}$ & $0.71(0.70 \text { to } 0.73)^{\star \star *}$ & $1.03(1.03$ to 1.04$)$ & $0.92(0.92 \text { to } 0.93)^{\star * *}$ \\
\hline \multicolumn{5}{|c|}{ Birth cohort (Ref: pre-World War) } \\
\hline World war II & 1.04 (0.89 to 1.22$)$ & $0.86(0.54$ to 1.38$)$ & $1.38(1.11$ to 1.71$)$ & $1.15(0.92$ to 1.44$)$ \\
\hline Older Baby Boomer & 0.85 (0.69 to 1.06$)$ & $0.68(0.45$ to 1.01$)$ & $1.38(1.13$ to 1.68$)$ & 1.06 (0.86 to 1.30$)$ \\
\hline Younger Baby Boomer & $0.71(0.53 \text { to } 0.96)^{\star \star *}$ & $0.55(0.39 \text { to } 0.79)^{\star \star \star}$ & $1.31(1.10$ to 1.56$)$ & $0.95(0.79$ to 1.15$)$ \\
\hline Gen X & $0.64(0.44 \text { to } 0.93)^{\star \star \star}$ & $0.48(0.28 \text { to } 0.81)^{\star \star \star}$ & $1.45(1.14 \text { to } 1.83)^{\star *}$ & $0.97(0.75$ to 1.25$)$ \\
\hline \multirow{2}{*}{\multicolumn{5}{|c|}{$\begin{array}{l}\text { Predisposing, enabling and behaviour-related } \\
\text { Education (Ref: } 16+\text { years) }\end{array}$}} \\
\hline & & & & \\
\hline $12-16$ years & $0.96(0.78$ to 1.19$)$ & $0.99(0.81$ to 1.21$)$ & $0.79(0.66 \text { to } 0.96)^{*}$ & $0.81(0.68 \text { to } 0.97)^{\star}$ \\
\hline$<12$ years & $0.91(0.72$ to 1.15$)$ & $0.93(0.75$ to 1.15$)$ & $0.57(0.46 \text { to } 0.69)^{\star \star *}$ & $0.57(0.47 \text { to } 0.70)^{\star \star \star}$ \\
\hline \multicolumn{5}{|c|}{ Income quartiles (Ref: bottom (Q1)) } \\
\hline Q2 & $0.92(0.85$ to 1.00$) \dagger$ & $0.96(0.89$ to 1.05$)$ & $0.95(0.88$ to 1.03$)$ & 0.99 (0.92 to 1.07$)$ \\
\hline Q3 & $0.94(0.86$ to 1.03$)$ & 0.98 (0.90 to 1.07$)$ & 1.00 (0.92 to 1.09$)$ & 1.06 (0.97 to 1.15$)$ \\
\hline Top (Q4) & $0.96(0.87$ to 1.05$)$ & $1.00(0.91$ to 1.10$)$ & $1.03(0.95$ to 1.13$)$ & $1.10(1.01 \text { to } 1.19)^{\star}$ \\
\hline Missing & $0.86(0.73$ to 1.02$) \dagger$ & $0.89(0.75$ to 1.04$)$ & $0.94(0.81$ to 1.10$)$ & $0.98(0.84$ to 1.14$)$ \\
\hline Have regular source of care & $3.82(3.45 \text { to } 4.23)^{\star \star \star}$ & $3.51(3.17 \text { to } 3.89)^{\star \star \star}$ & $1.44(1.30 \text { to } 1.60)^{\star \star *}$ & $1.30(1.17 \text { to } 1.44)^{\star \star \star}$ \\
\hline \multicolumn{5}{|l|}{ Smokers (Ref: never) } \\
\hline Current & $1.01(0.91$ to 1.11$)$ & $0.92(0.84$ to 1.01$)$ & $1.06(0.97$ to 1.16$)$ & $0.99(0.91$ to 1.07$)$ \\
\hline Former & 1.07 (0.98 to 1.16$)$ & 1.01 (0.93 to 1.09$)$ & $1.13(1.04 \text { to } 1.22)^{\star \star}$ & $1.07(0.99$ to 1.15$) \dagger$ \\
\hline \multicolumn{5}{|l|}{ BMI (Ref: normal)ף } \\
\hline Underweight & 1.080 .89 to 1.30$)$ & $1.08(0.90$ to 1.30$)$ & $1.11(0.93$ to 1.33$)$ & $1.12(0.94$ to 1.33$)$ \\
\hline Overweight & $1.31(1.22 \text { to } 1.42)^{\star \star *}$ & $1.24(1.15 \text { to } 1.33)^{\star \star \star}$ & $1.06(0.99$ to 1.14$) \dagger$ & 1.00 (0.93 to 1.07$)$ \\
\hline Moderate obese & $1.81(1.62 \text { to } 2.01)^{\star \star \star}$ & $1.52(1.37 \text { to } 1.68)^{\star \star \star}$ & $1.18(1.07 \text { to } 1.29)^{\star \star \star}$ & $1.01(0.92$ to 1.11$)$ \\
\hline Severe obese & $2.10(1.80 \text { to } 2.45)^{\star \star \star}$ & $1.53(1.32 \text { to } 1.77)^{\star \star \star}$ & $1.30(1.15 \text { to } 1.48)^{\star \star \star}$ & $0.99(0.87$ to 1.12$)$ \\
\hline Physically inactive & $0.90(0.85 \text { to } 0.95)^{\star \star \star}$ & $0.90(0.85 \text { to } 0.96)^{\star \star \star}$ & $0.88(0.83 \text { to } 0.92)^{\star \star \star}$ & $0.88(0.83 \text { to } 0.93)^{\star \star \star}$ \\
\hline Sedentary lifestyle & $1.09(1.02 \text { to } 1.17)^{\star}$ & $1.07(1.00 \text { to } 1.14)^{\star \star \star}$ & $1.13(1.06 \text { to } 1.21)^{\star \star \star}$ & $1.11(1.04 \text { to } 1.18)^{\star \star}$ \\
\hline \multicolumn{5}{|l|}{ Need for healthcare } \\
\hline \multicolumn{5}{|l|}{ Chronic conditions (Ref: none) } \\
\hline 1 & & $2.03(1.89 \text { to } 2.17)^{\star \star \star}$ & & $1.73(1.61 \text { to } 1.86)^{\star \star \star}$ \\
\hline $2+$ & & $3.30(3.03 \text { to } 3.60)^{\star \star *}$ & & $4.98(4.49 \text { to } 5.54)^{\star \star \star}$ \\
\hline \multicolumn{5}{|c|}{ 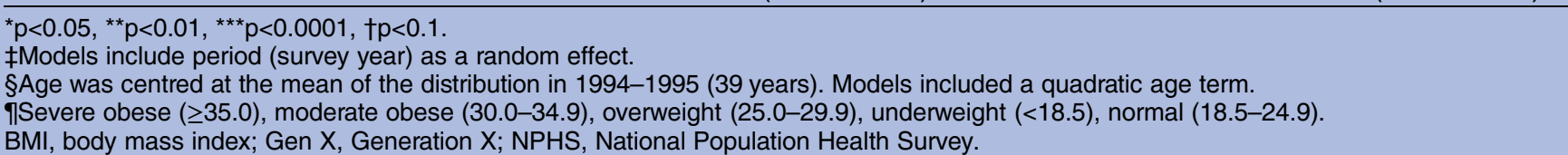 } \\
\hline
\end{tabular}

\section{Need factors: impact of chronic conditions}

As might be expected, the presence of chronic conditions was a significant and a strong predictor of primary care and specialist use. When we introduced the number of chronic conditions to the models, cohort differences in specialist care use were no longer significant (tables 3 and 4, model 3). In contrast, the opposite effect was seen for primary care use: cohort differences were augmented for women and became significant for men. Because of the dramatic change in the cohort effects, we hypothesised that there may be a differential impact of the number of chronic conditions on primary care use by birth cohort. To test this hypothesis, we conducted analyses that included interaction terms between chronic condition groups with age and cohort (see online supplementary table S1). The interactions with age and cohort were significant. As shown in figure 2, there were large cohort differences for women (figure 2A) and men (figure 2B) reporting two or more chronic conditions. When compared at corresponding ages, we found lower primary care use in each succeeding recent cohort. No cohort differences were seen for those with one or no chronic conditions.

\section{Supplementary analyses}

Findings of the models examining the number of visits to physicians were similar to our main results. Analyses that included each individual chronic condition revealed that cohort differences were virtually unchanged. This suggests that having multiple conditions, and not any specific condition, explained the cohort differences in the age trajectories of physician service use. Our models adjusting for drop-outs and mortality showed, as expected, higher overall primary care and specialist use 
Table 4 Predisposing, enabling, behaviour-related and need factors as predictors of physician use for men: results from logistic cross-classified multilevel models.‡ Canadian NPHS, 1994-2011

\begin{tabular}{|c|c|c|c|c|}
\hline & \multicolumn{2}{|l|}{ Primary care } & \multicolumn{2}{|l|}{ Specialist care } \\
\hline & $\begin{array}{l}\text { Model } 2 \\
\text { OR (95\% Cl) }\end{array}$ & $\begin{array}{l}\text { Model } 3 \\
\text { OR }(95 \% \mathrm{Cl})\end{array}$ & $\begin{array}{l}\text { Model } 2 \\
\text { OR }(95 \% \mathrm{Cl})\end{array}$ & $\begin{array}{l}\text { Model } 3 \\
\text { OR }(95 \% \mathrm{Cl})\end{array}$ \\
\hline \multicolumn{5}{|l|}{ Age and cohort effects } \\
\hline Linear age§ & $1.08(1.08 \text { to } 1.08)^{\star * *}$ & $0.85(0.85 \text { to } 0.85)^{\star * *}$ & $1.28(1.27 \text { to } 1.29)^{\star \star \star}$ & $1.08(1.08 \text { to } 1.09)^{\star * *}$ \\
\hline \multicolumn{5}{|c|}{ Birth cohort (Ref: pre-World War) } \\
\hline World War II & $1.08(0.82$ to 1.43$)$ & $0.87(0.64$ to 1.19$)$ & $1.35(1.06 \text { to } 1.72)^{\star *}$ & $1.12(0.88$ to 1.41$)$ \\
\hline Older Baby Boomer & $0.99(0.77$ to 1.28$)$ & $0.70(0.53 \text { to } 0.93)^{\star * *}$ & $1.36(1.09 \text { to } 1.71)^{\star *}$ & $1.00(0.81$ to 1.24$)$ \\
\hline Younger Baby Boomer & $0.86(0.68$ to 1.09$)$ & $0.54(0.42 \text { to } 0.70)^{\star \star \star}$ & $1.51(1.21 \text { to } 1.87)^{\star \star}$ & 0.99 (0.81 to 1.20$)$ \\
\hline Gen X & 0.79 (0.57 to 1.08$)$ & $0.46(0.32 \text { to } 0.65)^{\star \star *}$ & $1.73(1.32 \text { to } 2.28)^{\star \star \star}$ & $1.04(0.81$ to 1.34$)$ \\
\hline \multirow{2}{*}{\multicolumn{5}{|c|}{$\begin{array}{l}\text { Predisposing, enabling and behaviour-related } \\
\text { Education (Ref: } 16+\text { years) }\end{array}$}} \\
\hline & & & & \\
\hline $12-15$ years & $1.20(0.98$ to 1.48$)$ & $1.19(0.98$ to 1.43$)$ & $0.76(0.63 \text { to } 0.92)^{\star \star}$ & $0.75(0.63 \text { to } 0.90)^{\star \star \star}$ \\
\hline$<12$ years & $1.20(0.96$ to 1.50$)$ & $1.17(0.96$ to 1.44$)$ & $0.6(0.49 \text { to } 0.74)^{* * *}$ & $0.58(0.48 \text { to } 0.71)^{\star \star \star}$ \\
\hline \multicolumn{5}{|c|}{ Income quartiles (Ref: bottom (Q1)) } \\
\hline Q2 & $0.90(0.82 \text { to } 0.99)^{\star \star \star}$ & $0.94(0.86$ to 1.04$)$ & $1.01(0.91$ to 1.11$)$ & $1.07(0.97$ to 1.18$)$ \\
\hline Q3 & $0.90(0.81 \text { to } 0.99)^{\star \star \star}$ & $0.94(0.85$ to 1.04$)$ & $1.03(0.93$ to 1.14$)$ & $1.10(0.99$ to 1.22$) \dagger$ \\
\hline Top (Q4) & $0.84(0.75 \text { to } 0.93)^{\star * *}$ & $0.89(0.81 \text { to } 0.99)^{\star \star *}$ & 0.98 (0.88 to 1.09$)$ & 1.07 (0.96 to 1.18$)$ \\
\hline Missing & $0.69(0.56 \text { to } 0.87)^{\star \star *}$ & $0.71(0.57 \text { to } 0.88)^{\star * *}$ & $0.98(0.78$ to 1.23$)$ & $1.01(0.81$ to 1.26$)$ \\
\hline Have regular source of care & $3.36(3.06 \text { to } 3.68)^{\star \star *}$ & $3.03(2.77 \text { to } 3.32)^{\star \star \star}$ & $2.14(1.93 \text { to } 2.39)^{\star \star \star}$ & $1.86(1.67 \text { to } 2.06)^{\star \star \star}$ \\
\hline \multicolumn{5}{|l|}{ Smokers (Ref: never) } \\
\hline Current & $0.96(0.86$ to 1.07$)$ & $0.92(0.83$ to 1.02$)$ & $1.01(0.91$ to 1.13$)$ & $0.97(0.87$ to 1.07$)$ \\
\hline Former & 1.16 (1.06 to 1.28$)$ & 1.09 (0.99 to 1.19$)$ & $1.21(1.10 \text { to } 1.33)^{\star \star \star}$ & $1.15(1.04 \text { to } 1.26)^{\star \star \star}$ \\
\hline \multicolumn{5}{|l|}{ BMI (Ref: normal)ף } \\
\hline Underweight & $1.38(0.90$ to 2.10$)$ & $1.29(0.85$ to 1.97$)$ & $1.24(1.04 \text { to } 1.49)^{\star \star \star}$ & $0.96(0.80$ to 1.14$)$ \\
\hline Overweight & $1.14(1.05 \text { to } 1.23)^{\star * *}$ & $1.12(1.04 \text { to } 1.21)^{\star \star *}$ & $1.04(0.93$ to 1.17$)$ & 0.91 (0.82 to 1.02$)$ \\
\hline Moderate obese & $1.45(1.29 \text { to } 1.62)^{\star \star \star}$ & $1.30(1.17 \text { to } 1.45)^{\star \star \star}$ & $0.92(0.85$ to 1.00$) \dagger$ & $0.90(0.83 \text { to } 0.97)^{\star \star \star}$ \\
\hline Severe obese & $2.09(1.72 \text { to } 2.54)^{\star \star \star}$ & $1.69(1.40 \text { to } 2.03)^{\star \star \star}$ & $1.30(0.86$ to 1.97$)$ & $1.23(0.81$ to 1.86$)$ \\
\hline Physically inactive & $0.98(0.92$ to 1.04$)$ & 0.95 (0.89 to 1.01$)$ & $1.09(1.02 \text { to } 1.16)^{*}$ & $1.06(1.00$ to 1.14$) \dagger$ \\
\hline Sedentary lifestyle & $1.21(1.12 \text { to } 1.30)^{\star \star \star}$ & $1.14(1.06 \text { to } 1.23)^{\star \star \star}$ & $1.28(1.19 \text { to } 1.38)^{\star \star \star}$ & $1.21(1.12 \text { to } 1.31)^{\star \star \star}$ \\
\hline \multicolumn{5}{|l|}{ Need for healthcare } \\
\hline \multicolumn{5}{|l|}{ Chronic conditions (Ref: none) } \\
\hline 1 & & $2.27(2.11 \text { to } 2.44)^{\star \star \star}$ & & $2.03(1.87 \text { to } 2.21)^{\star \star *}$ \\
\hline $2+$ & & $4.04(3.69 \text { to } 4.43)^{\star \star \star}$ & & $6.86(5.99 \text { to } 7.87)^{\star \star *}$ \\
\hline \multicolumn{5}{|c|}{$\begin{array}{l}{ }^{*} \mathrm{p}<0.05,{ }^{* *} \mathrm{p}<0.01,{ }^{* *} \mathrm{p}<0.0001,+\mathrm{p}<0.1 \\
\text { †Models include period (survey year) as a random effect. } \\
\text { §Age was centred at the mean of the distribution in } 1994-1995 \text { (39 years). Models included a quadratic age term. } \\
\text { ๆSevere obese }(\geq 35.0) \text {, moderate obese }(30.0-34.9) \text {, overweight }(25.0-29.9) \text {, underweight }(<18.5) \text {, normal }(18.5-24.9) \text {. } \\
\text { BMI, body mass index; Gen X, Generation X; NPHS, National Population Health Survey. }\end{array}$} \\
\hline
\end{tabular}

among those who died during follow-up, but no impact on the effect of predisposing, enabling, need and behaviour-related risk factors on the outcomes. Further comparisons between those who died and those who were alive at the end of the study indicated that, although the age trajectory was steeper for those who died, cohort differences and the relationships of predisposing, enabling, need and behaviour-related factors remained unchanged. As a result, these analyses did not change the conclusions drawn from the main findings (tables available on request).

\section{DISCUSSION}

This is the first study to compare the lifecourse trajectories of physician visits among preboomers, baby boomers and Gen Xers. We found a modest decrease in the overall use of physician services in recent cohorts compared to previous cohorts. Specifically, the findings highlighted that there were different age and cohort patterns of primary care and specialist care use, suggesting an important shift in the pattern of healthcare use over time. Moreover, substantial cohort differences in primary care use were revealed when our additional analyses considered the differential impact of chronic conditions on physician services use. These analyses yielded marked cohort differences for those with multimorbidity. They showed lower primary care use in each succeeding recent cohort, so that at the same age Gen Xers were less likely to use primary care than Younger Baby Boomers and so on. In contrast to primary care use, we found that younger boomers and Gen Xers were more likely to report using specialist care. However, these cohort differences disappeared when healthcare needs, namely the number of chronic conditions, were taken 
A Women

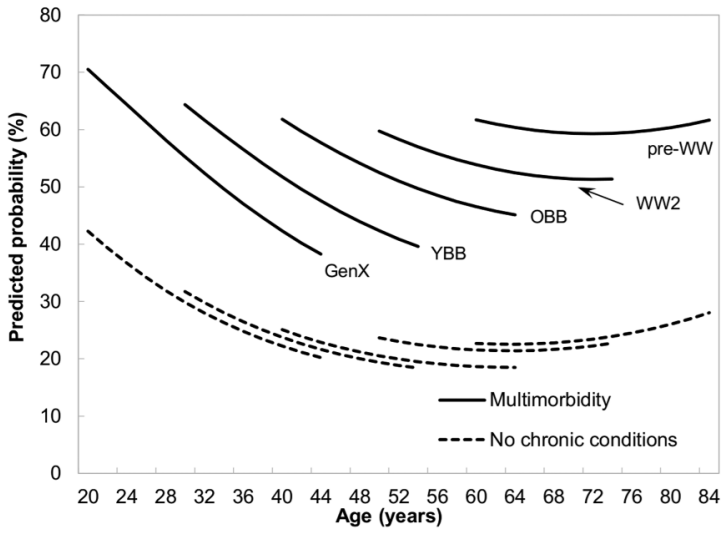

B Men

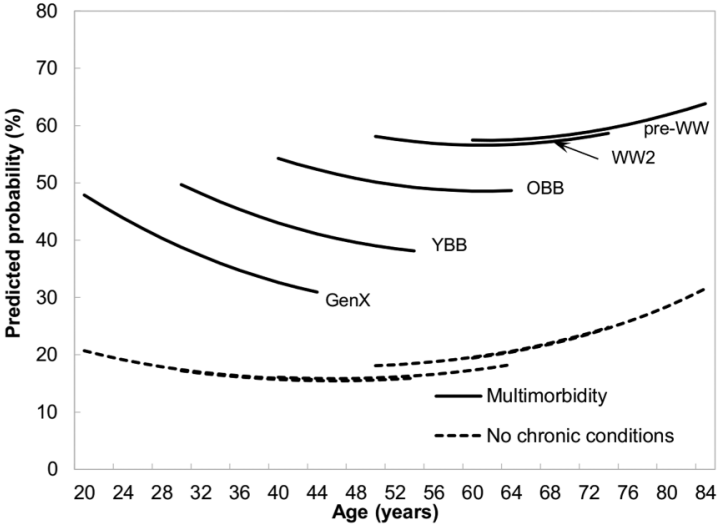

Figure 2 Age trajectories of primary care use by number of chronic conditions and birth cohort. Predictions from models with interactions between chronic condition groups and age, and with birth cohort. Models included predisposing, enabling, behavioural risk and need factors (see online supplementary table S1). GenX: Generation X; pre-WW: pre-World War II; OBB: Older Baby Boomer; WW2: World War II; YBB: Younger Baby Boomer.

into account. Juxtaposition of these findings suggest that there may be a shift from primary care to specialist care in more recent cohorts (eg, Gen Xers, younger boomers), particularly for those with multimorbidity.

\section{Comparison with other studies}

The lower primary care use for those with multimorbidity in recent cohorts is concerning for several reasons. First, more recent cohorts (ie, younger individuals) reported the most multimorbidity. ${ }^{43}$ It is unclear whether this reflects positive changes to the healthcare system with better access, earlier diagnosis and treatment or whether it reflects poorer health in more recent generations. Evidence from previous studies suggests that both factors may play a role. ${ }^{15} 4445$ Second, studies have highlighted the important role of FP/GPs in the integration and coordination of healthcare, especially for patients with chronic conditions. ${ }^{45-49}$ Our finding that cohort differences in specialist use were no longer apparent after accounting for healthcare needs suggests that the use of specialists by birth cohorts was largely related to need for care. Of potential concern, however, is that those with greater need for care are individuals from recent cohorts who may be developing multimorbidity at younger ages compared to their predecessors. ${ }^{43}$ An additional concern is that specialist services typically focus on chronic health conditions singly with the associated duplication of care and increased costs. ${ }^{46}$ This finding highlights the need to assess the balance between primary and specialty care to optimise healthcare delivery.

Our finding of greater use of specialists in conjunction with the lower primary care use among those with multimorbidity may also reflect changes in patient's preferences and expectations of more recent cohorts like Gen Xers and Younger Baby Boomers. ${ }^{18}{ }^{20}$ Alternatively, they may also be related to changing practice patterns of $\mathrm{FP} /$ GPs. Some research indicates that FP/GPs may be more likely to refer younger patients to specialists for the management of their chronic conditions. ${ }^{50}{ }^{51}$ It is also possible that members of recent cohorts have access to specialist investigations and treatment that were not available to earlier generations, which may account for differences across cohorts. Finally, in Canada, there have been an increase in the number of specialist relative to the number of FP/GPs over time, which may also contribute to the higher specialist use among recent generations. ${ }^{52}$ Future research is needed to examine primary care referrals, as well as patients' preferences and expectations in understanding the lower primary care use by individuals with multimorbidity.

Our study is consistent with previous research indicating greater healthcare use with older age ${ }^{1-3} 53$ and extends these findings by accounting for cohort effects. Predisposing, enabling and behaviour-related factors were important predictors of overall primary care and specialist use, but did not contribute to explaining the cohort differences in primary care and specialist use. Specifically, our findings of overall higher physician use by women are in line with previous studies. ${ }^{12}$ Also in keeping with past research were the findings of educational inequities in healthcare use: individuals with greater education were more likely to have used specialist care independently of the number of chronic conditions. ${ }^{1-3}$ Income showed variable findings and was only important for primary care use among men, such that lower income men were more likely to visit FP/ GPs. ${ }^{44}{ }^{53-55}$ Finally, similar to other studies, we found that obese individuals, current smokers, physically active and/or individuals with sedentary lifestyle used more health services. ${ }^{3056-59}$

\section{Strengths and limitations}

An advantage of this study is that longitudinal data enabled us to compare different cohorts at the same chronological age. The majority of the evidence on 
healthcare use in the population derives from crosssectional studies. ${ }^{2} 353$ However, it is impossible to study cohort effects in cross-sectional studies as comparing two cohorts at the same time point means that one is older than the other. Our approach provides an attractive methodology as we could integrate changes in healthcare use indicators with changes in factors associated with healthcare use. At the same time, the study has several limitations, particularly related to the survey's general methodology. Although data were collected about healthcare use and chronic conditions, there was no direct link between the two factors. Consequently, the interpretation of the findings is limited due to the inability to identify the specific conditions for which individuals are consulting with physicians. In addition, the NPHS data are selfreported and the bias associated with inaccuracies and reporting errors is unknown. It has been found that selfreports of healthcare use may underestimate actual physician visits, particularly among those with higher volumes of visits. ${ }^{60}$ However, because we dichotomised the outcomes, we do not expect that these under-reports affected our results and conclusions. Furthermore, additional analyses examining the number of visits provided similar results. Another limitation is that we were not able to examine the effect of ethnicity/cultural background as the vast majority (93.2\%) of participants identified themselves as white. ${ }^{39}$ Finally, there was attrition over the long follow-up time. We were able to examine the impact of mortality and loss to follow-up in our results. These analyses did not change our conclusions.

\section{Conclusions}

We found that overall cohort differences in physician services use were modest, but when examining use of primary and specialist care separately, cohort differences were larger for specialist use and in the opposite direction to that of primary care use. The higher specialist use and the lower primary care use of those with multimorbidity in recent cohorts suggest that there has been a shift from primary to specialty care among baby boomers and Gen Xers. Our findings underscore the importance of research and policies addressing generational differences in healthcare practices, expectations and preferences to ensure coordination and integration of healthcare delivery. If the trend of greater multimorbidity, lower primary care use and higher specialist use among recent cohort continues, the organisation and provision of healthcare in the near future will continue to face great challenges.

\footnotetext{
Author affiliations

${ }^{1}$ Institute of Medical Science, University of Toronto, Toronto, Ontario, Canada ${ }^{2}$ Krembil Research Institute, University Health Network, Toronto, Ontario, Canada

${ }^{3}$ Institute for Work and Health, Toronto, Ontario, Canada

${ }^{4}$ Institute for Clinical Evaluative Science, Toronto, Ontario, Canada

${ }^{5}$ Department of Family and Community Medicine, University of Toronto, Toronto, Ontario, Canada

${ }^{6}$ Department of Family and Community Medicine, St. Michael's Hospital, Toronto, Ontario, Canada
}

${ }^{7}$ Dalla Lana School of Public Health, University of Toronto, Toronto, Ontario, Canada

Acknowledgements Richard H Glazier is supported as a Clinician Scientist in the Department of Family and Community Medicine at the University of Toronto and at St. Michael's Hospital. We thank the Statistics Canada Research Data Centres Program for providing access to the data.

Contributors MC was the lead author on this paper. Her contributions included study design, statistical analysis and drafting of the manuscript. MG contributed to the design of the study, interpretation of results and critically revised the manuscript. SH-J contributed to the design, provided statistical advice and critically commented on the manuscript's content. RHG and EMB are the graduate supervisors of the lead author and provided guidance on the study design, analysis and structure of the manuscript. All authors read and approved the final manuscript and are accountable for all aspects of the study.

Funding This study was partially supported by a CIHR Operating GrantSecondary Analysis of Databases (SEC 117113).

Competing interests None declared.

Ethics approval University of Toronto Ethics Committee.

Provenance and peer review Not commissioned; externally peer reviewed.

Data sharing statement No additional data are available.

Open Access This is an Open Access article distributed in accordance with the Creative Commons Attribution Non Commercial (CC BY-NC 4.0) license, which permits others to distribute, remix, adapt, build upon this work noncommercially, and license their derivative works on different terms, provided the original work is properly cited and the use is non-commercial. See: http:// creativecommons.org/licenses/by-nc/4.0/

\section{REFERENCES}

1. Babitsch B, Gohl D, von Lengerke T. Re-revisiting Andersen's behavioral model of health services use: a systematic review of studies from 1998-2011. Psychosoc Med 2012;9:Doc11.

2. Glazier $\mathrm{RH}$, Agha MM, Moineddin R, et al. Universal health insurance and equity in primary care and specialist office visits: a population-based study. Ann Fam Med 2009;7:396-405.

3. Manski RJ, Moeller JF, Chen $\mathrm{H}$, et al. Patterns of older Americans' health care utilization over time. Am J Public Health 2013;103:1314-24.

4. Alemayehu B, Warner KE. The lifetime distribution of health care costs. Health Serv Res 2004;39:627-42.

5. Di Matteo $L$. The macro determinants of health expenditure in the United States and Canada: assessing the impact of income, age distribution and time. Health Policy 2005;71:23-42.

6. Neuman P, Cubanski J, Damico A. Medicare per capita spending by age and service: new data highlights oldest beneficiaries. Health Aff (Millwood) 2015;34:335-9.

7. Cangelosi PR. Baby boomers: are we ready for their impact on health care? J Psychosoc Nurs Ment Health Serv 2011;49:15-7.

8. Frey $\mathrm{WH}$. Baby boomers and the new demographics of America's seniors. Generations 2010;34:28-37.

9. Hampton T. Experts predict visits by baby boomers will soon strain emergency departments. JAMA 2008;299:2613-14.

10. Keehan S, Sisko A, Truffer C, et al. Health spending projections through 2017: the baby-boom generation is coming to medicare. Health Aff (Millwood) 2008;27:w145-55.

11. Knickman JR, Snell EK. The 2030 problem: caring for aging baby boomers. Health Serv Res 2002;37:849-84.

12. Cheung E. Baby boomers, generation $X$ and social cycles, volume 1: North American long waves. Toronto: Longwave Press, 2007.

13. Mellor MJ, Rehr H. Baby boomers: can my eighties be like my fifties? 1st edn. New York (NY): Springer, 2005.

14. Wister AV. Baby boomer health dynamics: how are we aging? Toronto: Toronto University Press, 2005.

15. Howard DH, Thorpe KE, Busch SH. Understanding recent increases in chronic disease treatment rates: more disease or more detection? Health Econ Policy Law 2010:5:411-35.

16. Crimmins EM, Beltrán-Sánchez $\mathrm{H}$. Mortality and morbidity trends: is there compression of morbidity? J Gerontol B Psychol Sci Soc Sci 2011;66:75-86 
17. Sulik GA, Eich-Krohm A. No longer a patient: the social construction of the medical consumer. In: Goldner M, Chambré SM, eds. Bingley, UK: Emerald Group Publishing Limited, 2008:3-28.

18. Foster MM, Earl PE, Haines TP, et al. Unravelling the concept of consumer preference: implications for health policy and optimal planning in primary care. Health Policy 2010;97:105-12.

19. Rosenthal M, Schlesinger M. Not afraid to blame: the neglected role of blame attribution in medical consumerism and some implications for health policy. Milbank Q 2002;80:41-94.

20. Kahana E, Kahana B. Baby boomers' expectations of health and medicine. Virtual Mentor 2014;16:380-4.

21. Pruchno R. Not your mother's old age: baby boomers at age 65 . Gerontologist 2012;52:149-52.

22. Andersen R, Newman JF. Societal and individual determinants of medical care utilization in the United States. Milbank Mem Fund $Q$ Health Soc 1973;51:95-124.

23. Andersen RM. National health surveys and the behavioral model of health services use. Med Care 2008;46:647-53.

24. Roberts L, Clifton RA, Ferguson B, et alRecent social trends in Canada 1960-2000. Montreal: McGill-Queen's University Press, 2005.

25. The Conference Board of Canada. How Canada performs: A Report card on Canada. http://www.conferenceboard.ca/Libraries/PUBLIC_ PDFS/13-260 HCP2013 ExecSumm.sflb

26. Chen X, Lin F, Stanton B, et al. Apc modeling of smoking prevalence among US adolescents and young adults. Am J Health Behav 2011;35:416-27.

27. Midlöv $\mathrm{P}$, Calling $\mathrm{S}$, Sundquist $\mathrm{J}$, et al. The longitudinal age and birth cohort trends of smoking in Sweden: a 24-year follow-up study. Int J Public Health 2014:59:243-50.

28. Piontek D, Kraus L, Muller S, et al. To what extent do age, period, and cohort patterns account for time trends and social inequalities in smoking? SUCHT 2010;56:361-71.

29. Badley EM, Canizares M, Perruccio AV, et al. Benefits gained, benefits lost: comparing baby boomers to other generations in a longitudinal cohort study of self-rated health. Milbank $Q$ 2015;93:40-72.

30. Azagba S, Sharaf MF, Xiao Liu C. Disparities in health care utilization by smoking status in Canada. Int $J$ Public Health 2013;58:913-25.

31. Allman-Farinelli MA, Chey T, Merom D, et al. The effects of age, birth cohort and survey period on leisure-time physical activity by Australian adults: 1990-2005. Br J Nutr 2009;101:609-17.

32. Reither EN, Hauser RM, Yang Y. Do birth cohorts matter? Age-period-cohort analyses of the obesity epidemic in the United States. Soc Sci Med 2009;69:1439-48.

33. Robinson WR, Keyes KM, Utz RL, et al. Birth cohort effects among US-born adults born in the 1980s: foreshadowing future trends in US obesity prevalence. Int J Obes (Lond) 2013;37:448-54.

34. Pilkington R, Taylor AW, Hugo G, et al. Are baby boomers healthier than generation $\mathrm{x}$ ? A profile of Australia's working generations using national health survey data. PLOS ONE 2014;9:e93087.

35. Allen L, Thorpe K, Joski $P$. The effect of obesity and chronic conditions on medicare spending, 1987-2011. PharmacoEconomics 2015;33:691-7.

36. Booth HP, Prevost AT, Gulliford MC. Impact of body mass index on prevalence of multimorbidity in primary care: cohort study. Fam Pract 2014;31:38-43.

37. Rice NE, Lang IA, Henley W, et al. Baby boomers nearing retirement: the healthiest generation? Rejuvenation Res 2010;13:105-14.

38. Leveille SG, Wee CC, lezzoni LI. Trends in obesity and arthritis among baby boomers and their predecessors, 1971-2002. Am J Public Health 2005;95:1607-13.
39. Statistics Canada. Information about the National Population Health Survey. Ottawa: Statistics Canada, 2011.

40. WHO. The use and interpretation of anthropometry report of a WHO expert committee technical report series, no 854. Geneva: WHO, 1995.

41. Bell A. Life-course and cohort trajectories of mental health in the UK, 1991-2008-a multilevel age-period-cohort analysis. Soc Sci Med 2014:120:21-30.

42. Suzuki E. Time changes, so do people. Soc Sci Med 2012;75:452-6; discussion 57-8.

43. Canizares M, Hogg-Johnson S, Gignac MA, et al. Lifecourse trajectories of multimorbidity in Canada: birth cohort differences and predictors. Paper presented at the 2016 Epidemiology Congress of the Americas Session: Aging Isn't Easy, and Neither is Analyzing Aging-Related Health Data: Novel Risk Factors and Applied Methods Miami, USA, 2016.

44. Bähler C, Huber CA, Brüngger B, et al. Multimorbidity, health care utilization and costs in an elderly community-dwelling population: a claims data based observational study. BMC Health Serv Res 2015;15:23.

45. Muggah E, Graves E, Bennett C, et al. The impact of multiple chronic diseases on ambulatory care use; a population based study in Ontario, Canada. BMC Health Serv Res 2012;12:452.

46. Barnett K, Mercer SW, Norbury M, et al. Epidemiology of multimorbidity and implications for health care, research, and medical education: a cross-sectional study. Lancet 2012;380:37-43.

47. Kirby MJL. Reforming health protection and promotion in Canada: time to act, 2002. http://www.parl.gc.ca/Content/SEN/Committee/ 372/soci/rep/repfinnov03-e.htm (accessed 26 Jan 2016).

48. Roland M, Guthrie B, Thomé DC. Primary medical care in the United Kingdom. J Am Board Fam Med 2012;25(Suppl 1):S6-11.

49. Phillips RL Jr, Bazemore AW. Primary care and why it matters for US. Health system reform. Health Aff (Millwood) 2010;29:806-10.

50. Adelman RD, Capello CF, LoFaso V, et al. Introduction to the older patient: a "first exposure" to geriatrics for medical students. J Am Geriatr Soc 2007;55:1445-50.

51. Band-Winterstein T. Health care provision for older persons: the interplay between ageism and elder neglect. J Appl Gerontol 2015;34:NP113-27.

52. Canadian Medical Association. Number and changing demographics of Canada's physicians over the years. https://www.cma.ca/En/ Pages/physician-historical-data.aspx

53. Jiménez-Rubio D, Smith PC, Van Doorslaer E. Equity in health and health care in a decentralised context: evidence from Canada. Health Econ 2008;17:377-92.

54. Allin S. Does equity in healthcare use vary across Canadian provinces? Healthc Policy 2008;3:83-99.

55. Beckman A, Anell A. Changes in health care utilisation following a reform involving choice and privatisation in Swedish primary care: a five-year follow-up of GP visits. BMC Health Serv Res 2013;13:452.

56. Peterson MD, Mahmoudi E. Healthcare utilization associated with obesity and physical disabilities. Am J Prev Med 2015;48:426-35.

57. Dogra S, Baker J, Ardern Cl. The role of physical activity and body mass index in the health care use of adults with asthma. Ann Allergy Asthma Immunol 2009;102:462-8.

58. Leigh JP, Hubert HB, Romano PS. Lifestyle risk factors predict healthcare costs in an aging cohort. Am J Prev Med 2005;29:379-87.

59. Atlantis E, Lange K, Wittert GA. Chronic disease trends due to excess body weight in Australia. Obes Rev 2009;10:543-53.

60. Reijneveld SA, Stronks K. The validity of self-reported use of health care across socioeconomic strata: a comparison of survey and registration data. Int J Epidemiol 2001;30:1407-14. 